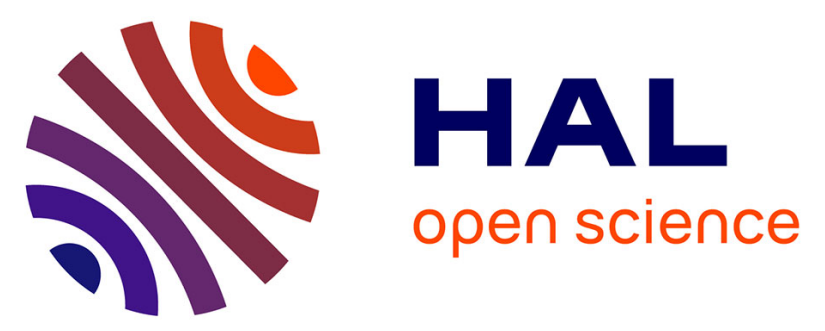

\title{
Solar to Hydrogen Conversion using Concentrated Multi-junction Photovoltaics and Distributed Micro-Converter Architecture
}

Kolja Neuhaus, Corinne Alonso, L. Gladysz, A. Delamarre, K. Watanabe, M. Sugiyama

\section{To cite this version:}

Kolja Neuhaus, Corinne Alonso, L. Gladysz, A. Delamarre, K. Watanabe, et al.. Solar to Hydrogen Conversion using Concentrated Multi-junction Photovoltaics and Distributed Micro-Converter Architecture. 7th International Conference on Renewable Energy Research and Applications (ICRERA 2018), Oct 2018, Paris, France. 10.1109/ICRERA.2018.8566763 . hal-01963506

\section{HAL Id: hal-01963506 \\ https://hal.laas.fr/hal-01963506}

Submitted on 22 Dec 2018

HAL is a multi-disciplinary open access archive for the deposit and dissemination of scientific research documents, whether they are published or not. The documents may come from teaching and research institutions in France or abroad, or from public or private research centers.
L'archive ouverte pluridisciplinaire HAL, est destinée au dépôt et à la diffusion de documents scientifiques de niveau recherche, publiés ou non, émanant des établissements d'enseignement et de recherche français ou étrangers, des laboratoires publics ou privés. 


\section{Solar to hydrogen conversion using concentrated multi-junction photovoltaics and distributed micro- converter architecture}

\author{
K. Neuhaus, C. Alonso \\ ISGE, LAAS-CNRS \\ Université Paul Sabatier \\ Toulouse, France \\ kneuhaus@laas.fr, alonsoc@laas.fr
}

\author{
L. Gladysz, A. Delamarre, K. Watanabe, M. Sugiyama \\ Sugiyama Laboratory, Research Center for Advanced \\ Science and Technology \\ The University of Tokyo \\ Tokyo, Japan
}

\begin{abstract}
Conversion of solar energy to hydrogen has been identified as a viable solution for renewable energy development known as solar fuel. LAAS (Toulouse) and RCAST (Tokyo) laboratories have associated in the framework of the NextPV LIA in order to respond to technological challenges concerning solar fuel studies in order to develop optimal sizing methodologies. A system structure for high efficiency solar to hydrogen energy conversion was developed, comprising multi-junction concentrated photovoltaic solar cells, a distributed DC/DC converter architecture, PEM electrolysis, and a battery storage buffer. Experimental results are obtained through a prototype of the proposed structure.
\end{abstract}

Keywords - Solar fuels - distributed power architectures - DC nanogrid - conversion efficiency - Electrolysis - DC/DC converter CPV-optimal energy management- hybrid storage for nanogrids

\section{INTRODUCTION}

According to the National Renewable Energy Laboratory (NREL), 4 categories of solar photovoltaic production exist [1] which are crystalline Silicon cells, single-junction GaAs cells, thin-film technologies and multijunction Cells [2]. For the purpose of attaining maximum solar to hydrogen conversion efficiency, the multijunction solar cell technology is chosen for our study. A cell with four or more junctions can attain up to $40 \%$ solar to electrical conversion efficiency [3] and even up to $46 \%$ when using an appropriate concentration device [4]. Solar concentration can be obtained through parabolic mirrors or Fresnel lenses. An automated solar tracking device is needed in order to keep the focal point of concentration aligned with the panels.

Hydrogen can be produced through water electrolysis using different technologies such as alkaline electrolysis, proton exchange membrane (PEM) and solid oxide electrolyzer cells (SOEC). Among them, the PEM technology was identified for being particularly adapted to renewable energy systems. In fact, PEM electrolyzers are less impacted by power intermittencies that can occur with solar energy, have a higher efficiency, can be used at atmospheric pressure (and up to several hundred bar) and profit from the increasing cost reduction due to fuel cell development using the same materials [5].

The goal of this study is to design a power architecture able to supply energy for electrolysis without interruption over 24 hours. The focus is made on distributed converter architectures for modularity and flexibility in power supply with a multicriteria optimization regarding efficiency, robustness, power scalability and cost.

Solar to hydrogen conversion efficiency has been topped in cases of direct electrical connection between concentrated multi-junction photovoltaic cells (CPV) and PEM electrolyser cells. Current records are around $24 \%$ to $30 \%$ efficiency between solar energy and produced hydrogen [6], [7]. This paper focuses on the principle of optimized solar fuel hydrogen production through electrolysis with the goal of obtaining the highest conversion efficiency between solar energy and produced hydrogen. LAAS and RCAST laboratories have associated In the NextPV international lab to propose an optimized conversion structure in this paper. The structure of the system will be detailed in section 2 .

\section{SYSTEM STRUCTURE}

The structure proposed for this study is a complete solar to hydrogen conversion system comprising multi-junction solar cells with appropriated Fresnel lenses for concentration and a solar tracking system, a power electronic converter stage with maximum power tracking algorithm (MPPT), a Lithium-ion battery storage device for maximum energy availability and PEM electrolyzer cells for hydrogen production supplied through a Buck converter stage. The global system concept is described in fig. 1 .

Each part of the system will be described in the following sections. 


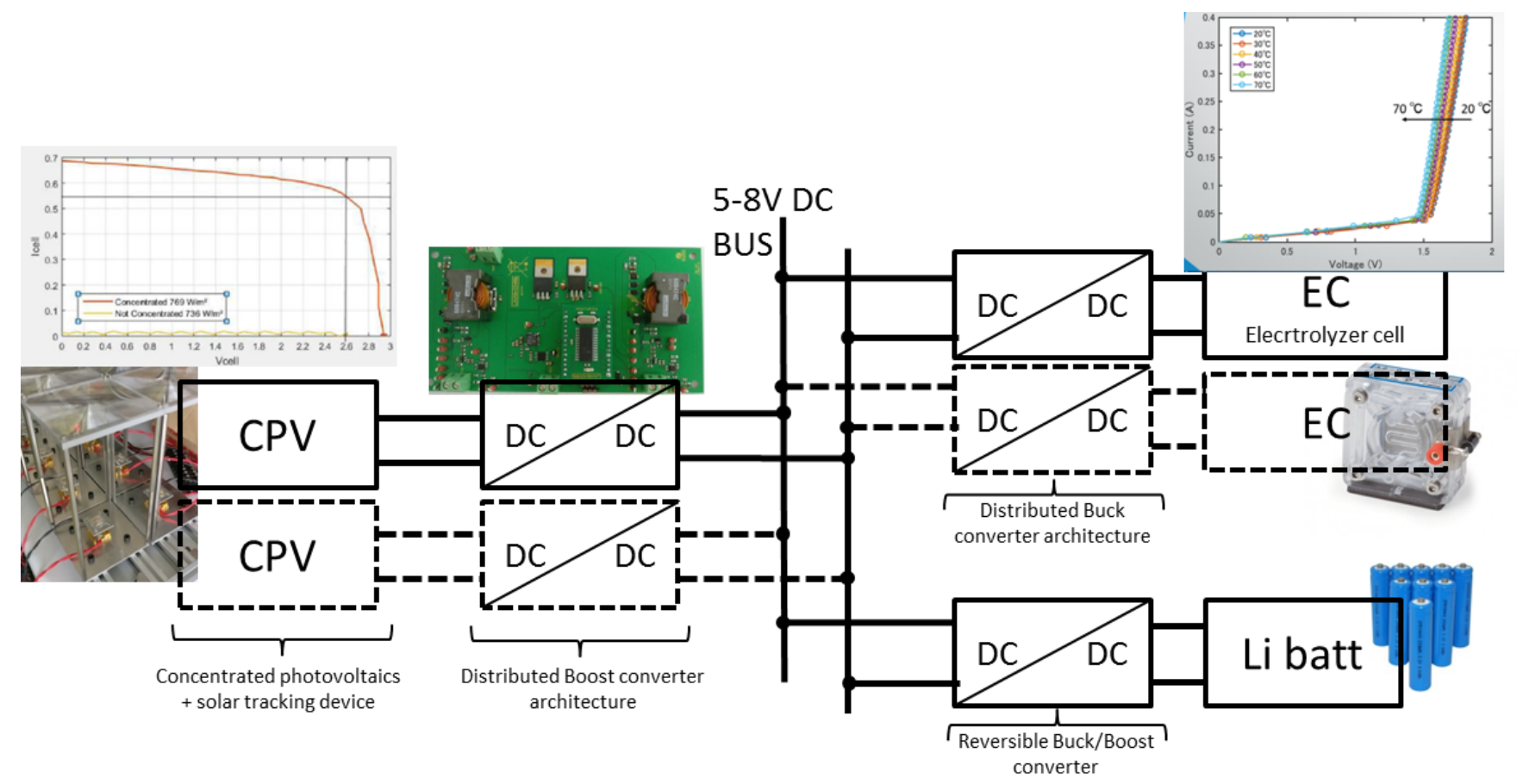

Figure 1: Schematic of the complete solar to hydrogen conversion system

\section{A. Solar cells}

The multi-junction solar cells chosen for this prototype are composed of a superposition of three junctions capable of absorption in a wavelength spectrum ranging roughly from 300 $\mathrm{nm}$ to $1700 \mathrm{~nm}$ in comparison to $1100 \mathrm{~nm}$ [8] for standard silicon cells. The cells used in this project were designed in the RCAST laboratory in the University of Tokyo and can be seen on fig. 2.

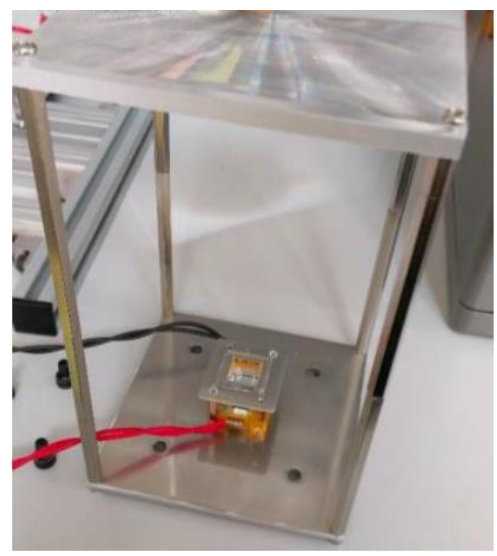

\section{B. Distributed DC/DC BOOST Converter architecture for CPV}

A power converter stage is added to the solar cells in order to improve their production through maximum power point tracking (MPPT). A distributed converter architecture as shown in fig. 1 is chosen. Each multi-junction solar cell is paired with a micro Boost power converter in order to reach absolute maximum power output on each cell. Power losses due to cell or concentration disparity are minimized this way. A schematic of the Boost converter is given in fig. 3 .

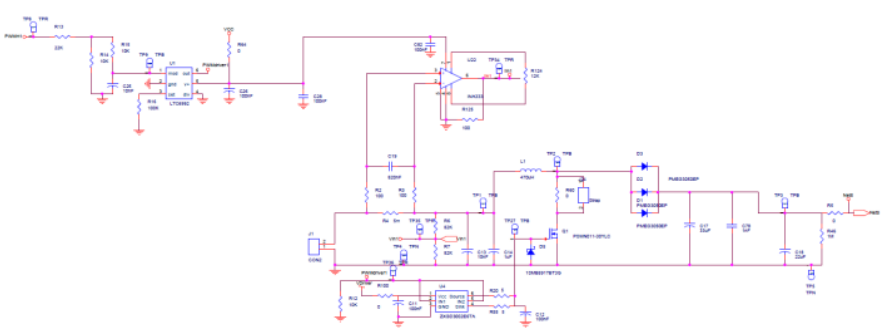

Figure 3: schematic structure of the proposed micro Boost converter architecture

A standard numeric Hill Climbing MPPT command is

Figure 2: Triple junction solar cell designed in RCAST equipped with Fresnel lens and prism for concentration

Each multi-junction cell has a maximum power output around 1.5 Watt at standard test conditions. These cells are placed on an automatized 2-axis solar tracking device commanded with a time derived astronomical position system (TDAPS) installed on the roofs of the ADREAM platform [9] in the LAAS laboratory, Toulouse. A cell efficiency of $31 \%$ is achieved [6]. applied to each converter separately through an extra low power dsPIC microcontroller (XLP). A power efficiency ranging from $92 \%$ to $95 \%$ is achievable with the use of an extra low power controller for the desired current range of $0,2 \mathrm{~A}$ to $0.5 \mathrm{~A}$ per solar cell as seen in fig. 4 below. 


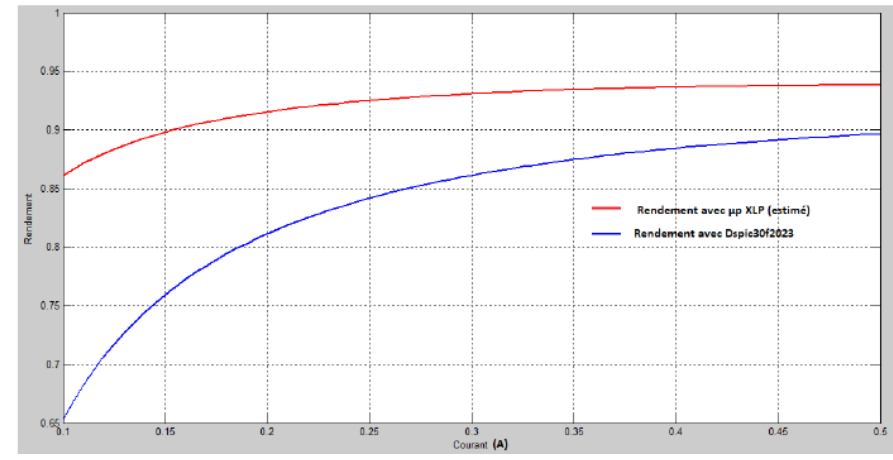

Figure 4: CPV Boost converter efficiency with two different microcontrollers, PIC30f2023 (blue) and PIC18FL27K40 (red, simulated)

\section{Electrolyzer cells}

Two small scale PEM electrolyzer cells from the brands $\mathrm{H}-$ TEC and HORIZON have been studied and modelized for being used in this demonstrator. Each cell has been tested for their specific voltage ranges in order to determine the optimal functioning point for maximal efficiency of electrolysis. The $\mathrm{H}-\mathrm{Tec}$ cell has been identified as the most suited for this project. Experimental test results for this cell are shown in Table 1.

TABLE 1: EXPERIMENTAL RESULTS FOR THE H-TEC ELECTROLYZER CELL

\begin{tabular}{|l|l|l|l|l|l|}
\hline $\begin{array}{c}\text { Voltage } \\
(\mathbf{V})\end{array}$ & $\begin{array}{c}\text { Current } \\
(\mathbf{A})\end{array}$ & $\begin{array}{c}\text { Consumed } \\
\text { energy }(\mathbf{W s})\end{array}$ & $\begin{array}{c}\text { Volume of } \\
\text { Hydrogen } \\
(\mathbf{c m 3} / \mathbf{m i n})\end{array}$ & $\begin{array}{c}\text { Equivalent } \\
\text { energy } \\
(\mathbf{W s})\end{array}$ & $\begin{array}{c}\text { Efficiency } \\
(\%)\end{array}$ \\
\hline 1,6 & 0,15 & 14,4 & 0,5 & 5,4 & 37,5 \\
\hline 1,7 & 0,39 & 39,7 & 1,5 & 16,2 & 40,72 \\
\hline 1,8 & 0,5 & 54.0 & 4.0 & 43,17 & 80.0 \\
\hline 1,9 & 0,78 & 88,9 & 6.0 & 64,76 & 72,83 \\
\hline 2 & 1,02 & 122,4 & 8.0 & 86,35 & 70,55 \\
\hline 2,1 & 1,26 & 158,7 & 9,5 & 102,54 & 64,58 \\
\hline 2,2 & 1,48 & 195,3 & 11.0 & 118,73 & 60,77 \\
\hline 2,3 & 1,7 & 234,6 & 13.0 & 140,32 & 59,81 \\
\hline 2,4 & 1,92 & 276,4 & 15.0 & 161,9 & 58,56 \\
\hline
\end{tabular}

After examining the test results, maximum efficiency is achieved for the H-TEC cell at $1.8 \mathrm{~V}$ and $0.5 \mathrm{~A}$ with an efficiency of $80.0 \%$. The HORIZON cell showed an efficiency of $73.5 \%$ at $1.8 \mathrm{~V}$ with a current of $0.68 \mathrm{~A}$. In addition, it appeared during these tests that electrolyzer cell's performance suffers from repeated startup phases and needs a consistent energy source. Fixing the input voltage of the cells at a constant $1.8 \mathrm{~V}$ is therefore desired. However, photovoltaic energy production is highly intermittent and dependent on weather conditions. A separate stage of conversion is needed in order to overcome this inconvenience.

\section{Distributed DC/DC BUCK converter architecture for electrolyzer cells}

In order to fix the input voltage for the electrolyzer cell, a distributed Buck converter stage is added. The synchronous Buck structure shown in fig. 4 below is chosen in order to reduce conduction losses and increase the overall efficiency of the system.

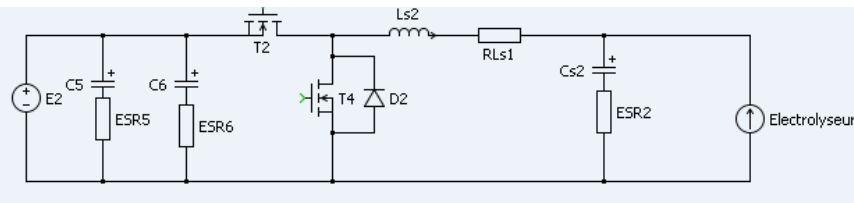

Figure 5: Simplified structure schematic for the micro Buck converters suppliying the electrolyzer cells.

An output voltage regulation is applied to this converter through a proportional integral (PI) corrector in order to keep the chosen electrolyzer cells working at their optimal efficiency at $1.8 \mathrm{~V}$. This corrector is applied through an extra low power DsPic microcontroller identical to the one described in section II-B.

The choice is made to use a lithium-ion battery cell as an energy storage buffer to provide stable energy provision without discontinuity due to intermittency and day/night cycles as well as to power both stages of converters in an optimal way.

\section{CONCLUSION}

A small scale solar to hydrogen conversion system has been designed with the goal of maximum hydrogen production efficiency. It has been shown that the individual stages of the conversion chain have each an efficiency that can be calculated. At its current stage of development, with a CPV system efficiency of roughly $31 \%$, a converter efficiency of $95 \%$ and an electrolysis efficiency of $80 \%$, it is theoretically possible to obtain a total solar to hydrogen conversion efficiency around $23.5 \%$ in simulation as compared to $24 \%$ from direct connection, with the addition of control and degrees of freedom.

These promising preliminary results constitute a basis for further investigation in the field of small scale solar to hydrogen conversion and have to be experimentally validated with the prototype chain proposed in this paper. The study of micro-power converters adapted to electrolyzer cells and the impedance spectroscopy based modelization of electrolyzer cells for a better understanding of their functioning are both topics of ongoing research.

\section{ACKNOWLEDGMENT}

A special acknowledgement goes to the NeoCampus [10] group from the University Paul Sabatier in Toulouse for financing a thesis and supporting the studies done in its frame. 


\section{REFERENCES}

[1] « National Center for Photovoltaics | Photovoltaic Research | NREL ». [Online]

[2] Fraunhofer Institute for Solar Energy ISE. 2014 press release [Online]

[3] R. R. King et al., « $40 \%$ efficient metamorphic GaInP/GaInAs/Ge multijunction solar cells », Appl. Phys. Lett., vol. 90, no 18, p. 183516 , avr. 2007

[4] X. Zhang, V. A. Öberg, J. Du, J. Liu, et E. M. J. Johansson, « Extremely lightweight and ultra-flexible infrared light-converting quantum dot solar cells with high power-per-weight output using a solution-processed bending durable silver nanowire-based electrode », Energy Environ. Sci., 2018 [Online]

[5] O.Schmidt, A.Gambhir, I.Staffell, A.Hawkes, J.Nelson, S.Few, "Future cost and performance of water electrolysis: an expert elicitation study", International Journal of Hydrogen Energy, 2017 ELSEVIER
[6] A. Nakamura, Y. Ota, K. Koike, Y. Hidaka, K. Nishioka, M. Sugiyama, and K. Fujii, "A $24.4 \%$ solar to hydrogen energy conversion efficiency by combining concentrator photovoltaic modules and electrochemical cells", APEX - 2015

[7] J. Jia, L.C. Seitz, J.D. Benck, Y. Huo, Y. Chen, J.W.D. Ng, T. Bilir, J.S. Harris, and T.F. Jaramillo, "Solar water splitting by photovoltaicelectrolysis with a solar-to-hydrogen efficiency over 30", Nat. Commun. 7, 13237 (2016).

[8] S.W. Glunz, R. Preu, D. Biro, «Crystalline Silicon Solar Cells » published in «Comprehensive Renewable Energy » ISBN 978-0-08087873-7, 2012 by ELSEVIER

[9] REF ADREAM

[10] NeoCampus, https://www.irit.fr/neocampus/fr/, Université Paul Sabatier Toulouse, [Online] 